Article

\title{
Exploring the Institutional and Bottom-Up Actions for Urban Air Quality Improvement: Case Studies in Antwerp and Gdańsk
}

\author{
Joanna Badach ${ }^{1, *(D)}$, Małgorzata Dymnicka ${ }^{2}$, Jarosław Załęcki ${ }^{3}$, Maciej Brosz ${ }^{3} \mathbb{D}$, Dimitri Voordeckers 4 \\ and Maarten Van Acker 4
}

check for updates

Citation: Badach, J.; Dymnicka, M.; Załęcki, J.; Brosz, M.; Voordeckers, D.; Van Acker, M. Exploring the Institutional and Bottom-Up Actions for Urban Air Quality Improvement: Case Studies in Antwerp and Gdańsk. Sustainability 2021, 13, 11790. https:/ / doi.org/10.3390/su132111790

\section{Academic Editors: Karolina}

M. Zielinska-Dabkowska and Carlos Oliveira Cruz

Received: 30 August 2021

Accepted: 19 October 2021

Published: 25 October 2021

Publisher's Note: MDPI stays neutral with regard to jurisdictional claims in published maps and institutional affiliations.
1 Department of Urban Architecture and Waterscapes, Faculty of Architecture, Gdańsk University of Technology, 11/12 Narutowicza Street, 80-233 Gdańsk, Poland

2 Department of Urban Design and Regional Planning, Faculty of Architecture, Gdańsk University of Technology, 11/12 Narutowicza Street, 80-233 Gdańsk, Poland; mdym@pg.edu.pl

3 Department of Applied Sociology, Institute of Sociology, University of Gdańsk, 4 Bażyńskiego Street, 80-309 Gdańsk, Poland; jaroslaw.zalecki@ug.edu.pl (J.Z.); maciej.brosz@ug.edu.pl (M.B.)

4 Research Group for Urban Development, Faculty of Design Sciences, University of Antwerp, Mutsaardstraat 31, 2000 Antwerp, Belgium; dimitri.voordeckers@uantwerpen.be (D.V.); maarten.vanacker@uantwerpen.be (M.V.A.)

* Correspondence: joanna.badach@pg.edu.pl

\begin{abstract}
The article presents the results of qualitative studies concerning the presence of air quality management in the process of urban planning and in the public discourse in Antwerp, Belgium, and Gdańsk, Poland. We focused on the way urban planners, environmental experts, and stakeholders perceive the problem of air pollution, especially with respect to urban development policy, and whether they consider it one of the major factors determining the quality of the urban built environment. The analysis was empirically based on free, partially structured interviews with experts. With that aim, we referred to certain assumptions of the multidimensional concept of environmental protection and integrated urban planning, highlighting the knowledge gained through interview analysis, literature review, and comparative case study research. The approach brings to light the difference between the perceived and measured air quality and to what extent it is affected by the spatial conditions. The research reveals how the range of perceptions of air pollution is embedded in several sociological, urban planning, and cultural perspectives and how these perceptions differ between the different profiles of the stakeholders and experts.
\end{abstract}

Keywords: air pollution; air quality management; environmental participation; integrated urban planning; public discourse

\section{Introduction}

The issues of the relationship between the environment and society are becoming increasingly present not only in the academic discourse and international politics, but also in the mass media, pop culture, marketing strategies of private enterprises, or the consumption styles promoted by the commercial sector. Ecology has become a permanent element of sociological reflection and research as interventions by various stakeholders and bottom-up initiatives are becoming intertwined, bringing new perspectives and solutions for improving the quality of the environment and modes of environmental governance.

In particular, Beck's theory of the 'world risk society' has played an important role in the debates concerning environmental issues, directing the sociological discourse towards the unknown and unintentional consequences and ecological threats of industrialisation and modernisation. According to Beck, this process of unprecedented extent affects all aspects of our life [1]. Both Beck and Giddens refer to the concept of reflexivity as a response to the uncertainties of the risk society, in which the current social practices must 
be constantly examined and reformed in terms of their impact on the environment $[2,3]$. It permeates various areas of social life and it is crucial to exploring the current modes of environmental governance, participation, and policy formulation. It is aimed at managing the current and future risks to human health and well-being both at the macro and micro level $[3,4]$. The concepts of environmental justice and citizenship are also worth mentioning when discussing environmental theory $[5,6]$. However, most importantly, the concept of sustainable development seems to be a globally approved solution. The ideas of sustainable development, ecological modernisation, environmental justice, and citizenship involve responsibilities towards future generations, promoting vital changes in the relationship between the society and environment and in the way social inequalities are addressed.

Sustainable development is one of the key issues of the contemporary restructuring of urban areas and the process of urban planning, which can play a vital role in implementing the solutions for the improvement of the environmental quality $[7,8]$. Ecological issues, including air quality, climate change, local microclimatic conditions or thermal comfort, as well as their perception by the users of the urban space, are gaining importance because they are increasingly perceived as a broader context of social problems (including political, cultural, and economic issues) [9-15]. In our opinion, in times of advanced modernisation and global factors of change, reflexivity, and the new awareness of ecological consequences and threats, also expressed in social awareness, mentality, and in the language of the various stakeholders, deserve special attention. Reflexivity is a means of control which implies controlling one's own activities and expecting the same from others [16-18]. Therefore, we referred to this concept to examine the social and urban planning practices related to air pollution mitigation and to explore how local planning and governance processes are evaluated and re-shaped by various stakeholders in order to achieve urban air quality improvement. Air pollution continues to exceed the guideline limits, especially in large urban agglomerations [19]. Despite the fact that in Europe emissions of many air pollutants have been reduced in recent years, a significant proportion of European residents still lives in places where the air quality surpasses the EU legal values. In the year 2014 alone, approx. 400,000 people died in Europe as a result of long-term exposure to air pollution [20]. Therefore, urban development policy and planning practice need to be updated to minimise the negative impact of low air quality on health and well-being of urban inhabitants [21-24].

The issue of air pollution has already been present in the formulation of urban spatial development or mobility policies for a couple of decades. Recently, more precise predictions of the impact of urban form and planning solutions on air quality and the wind environment have become more common, especially due to the development of computational modelling tools [25]. Moreover, in many countries and cities, planning regulations or guidelines for urban ventilation and air quality improvement are implemented, such as the air ventilation assessment (AVA) of Hong Kong [26] or the wind microclimate recommendations of the city of London [27]. However, such an evaluation still requires expert knowledge and considerable resources. Therefore, the full understanding of the wind environment and pollution dispersion phenomena, as well as their consideration in the process of shaping the built environment, still require further research $[25,28]$.

Moreover, recently the need to include the social and urban policy aspects in the research regarding urban air quality improvement has also been emphasised. Numerous actions for pollution mitigation, such as urban mobility control measures and the popularisation of public transport [29-31], or the promotion of sustainable urban living, e.g., in the form of Low Emission Neighbourhoods [32], require the acceptance, and very often also the active participation, of the urban residents. Therefore, the issue of the public awareness of air pollution is gaining academic recognition (see, e.g., some recent studies related to outdoor air quality social perception [33-35]). The results of such studies suggest that public support for air pollution mitigation strategies is a crucial factor in their successful implementation [36-39]. Moreover, the accurate perception of the risk associated with exposure to air pollution may also generate appropriate social practices [40]. In this study, 
the issue of the development of the urban planning policy and public debate on air quality in two European cities, Antwerp (Belgium) and Gdańsk (Poland), was addressed.

Belgium, like many other European countries characterised by high population density, significant economic activity, and large-scale process of urban sprawl, is associated with severe air pollution issues [41]. A major source of air pollution emissions in Belgium is the combustion of fossil fuels in the transport sector, especially from individual vehicles [42]. This could be observed during the lockdown measures implemented in Europe in March 2020 to contain the COVID-19 pandemic, when lower $\mathrm{NO}_{2}$ concentrations were observed due to extensive traffic reductions [43].

According to some alarming reports, air quality management in Poland is highly inefficient. For example, the WHO database on urban ambient air quality (2016 and 2017 update) indicated that, respectively, 33 and 36 out of 50 most polluted cities in the European Union (EU) were located in Poland [44]. As ruled by the Court of Justice of the EU (2018), the European directive on ambient air quality was not fulfilled in Poland. Due to the lack of proper air quality protection programmes, the limit values of PM10 are exceeded in many areas. [45]. Unlike in Belgium, the major air pollution sources in Poland are related to energy policies based on fuel combustion and the out-dated infrastructure for household heating [46].

Both in Belgium and in Poland, the urban atmospheric pollution, and especially the high concentration episodes, are gaining particular attention in the public debate. However, a recent extensive study investigating air pollution perception across Europe indicates that this issue is still poorly recognised [47]. This article shows the prominence of the issue of addressing air quality management in the urban built environment based on the opinions expressed by local experts. The design and the methodological approach of the study were based on the assumption that local planning and social practices, adapted to the particular urban conditions, are essential to achieving sustainability and environmental objectives. The aim was to explore how such local spatial planning policies and community practices can lead to the implementation of the solutions for urban air quality improvement.

By employing the qualitative approach we showed that the issue of urban air quality involves not only a variety of opinions among the different professional and social groups, but also the different ways in which the problem is discussed, including among experts. The statements of the participants of the ecological discourse emphasised the relational and multidimensional links between the urban built environment, the urban nature, and the socio-cultural context. We addressed the environmental problem of air pollution in broader spatial and social terms and evaluated the state of the public debate and urban policy regarding the issue of urban air quality in two case studies.

We presented translations of the problem voiced by various public actors (planners and architects, representatives of urban institutions and civic movements, academics, and inhabitants), acknowledging the assumption that environmental problems are socially constructed. Sociological environmental studies are focussing on the tension between social constructionists and critical realists. Both positions, although each of them is marked by limitations, deserve notice. The former consists of an attempt at seeing spatial and environmental problems through the prism of the social context [48], while the latter combines data accumulated by representatives of social, natural, and technical sciences [49]. From this perspective, it is important to see the relation between scientific and other discourses to practice, and whether the former impact the latter and vice versa. We aimed to show the complexity and ambiguity of the analysed problem area on the basis of expert interviews. Air pollution is also considered a problem rooted in civilisation and culture, related to the theory of consumer societies. Environmental citizenship and justice direct us to those urban areas which generate most of the air pollutants [50,51]. 


\section{Materials and Methods}

\subsection{Study Areas}

Two cities were included in the study-Antwerp, Belgium and Gdańsk, Poland. Both cities host major ports: the port of Antwerp, one of the biggest ports in Europe, and the port of Gdańsk, the largest Polish sea port. However, the morphological structure (see Figures 1 and 2) and planning systems, as well as air pollution mitigation strategies, differ in the two cities.

Antwerp, a city with a resident population of over 520,000 and a size of $204.5 \mathrm{~km}^{2}$, is the largest city in the Flemish part of Belgium. Nowadays, the city is a diverse centre of business activities and it is responsible for an important part of the Flemish economy. The city cherishes the ambition to develop a "sustainably competitive" position in the region, at the same time increasing its liveability and attractiveness. A policy of horizontal governance, integrated planning, and communication with the citizens are the key factors in this process [52].

Gdańsk, a city with a resident population of over 460,000 and a size of $262 \mathrm{~km}^{2}$, is located in northern Poland on the Baltic Sea coast. It is a part of the Tri-City urban agglomeration (together with Gdynia and Sopot). Because of the Solidarity movement that originated in Gdańsk in the 1980s, it has become an iconic city for its role in bringing down communism in the Eastern Block. Nowadays, Gdańsk is a cultural, economic, and educational centre in Central Europe, but it is struggling to adapt to the spatial, economic, and demographic changes and to re-define its identity in the network of modern cities [53-56].

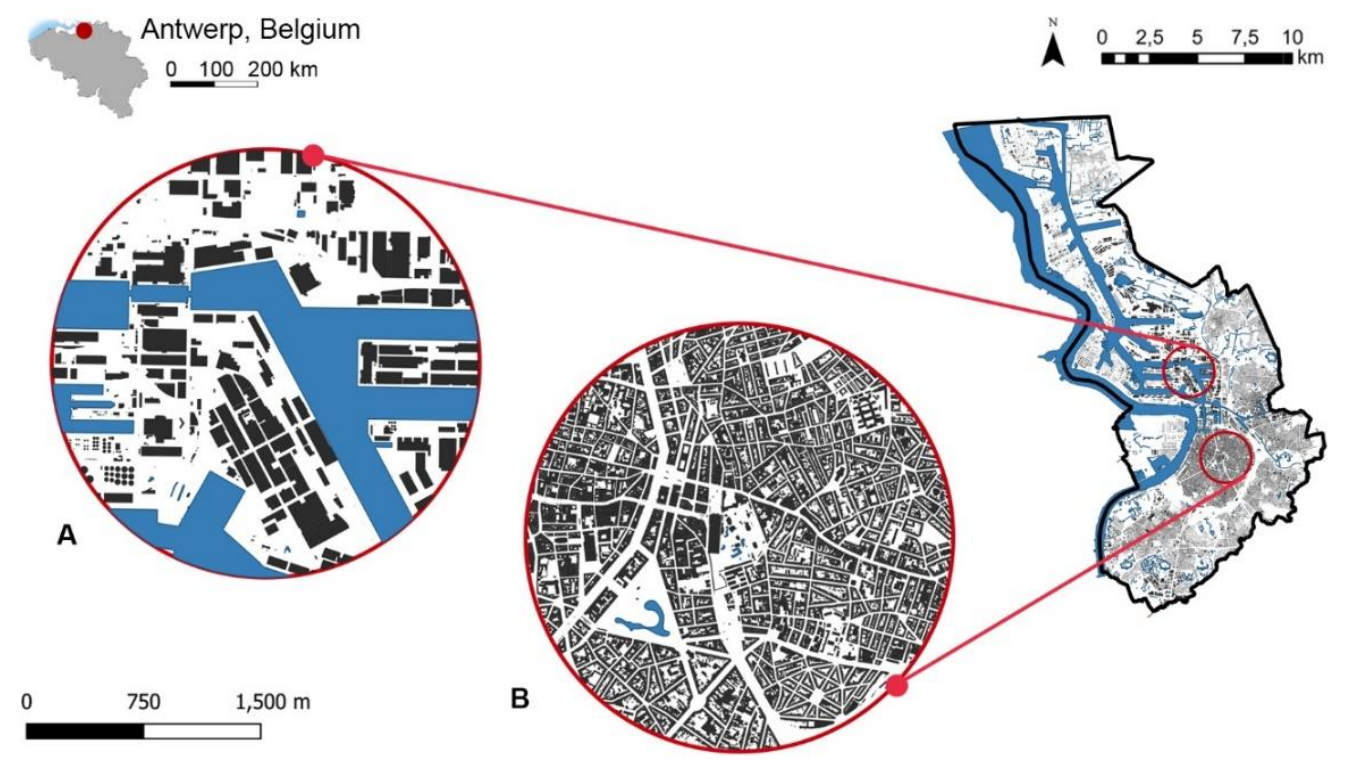

Figure 1. The location and urban fabric of the city of Antwerp: (A) densely built-up urban fabric of the historic centre, (B) urban fabric of the port. Own elaboration, data source: [57]. 


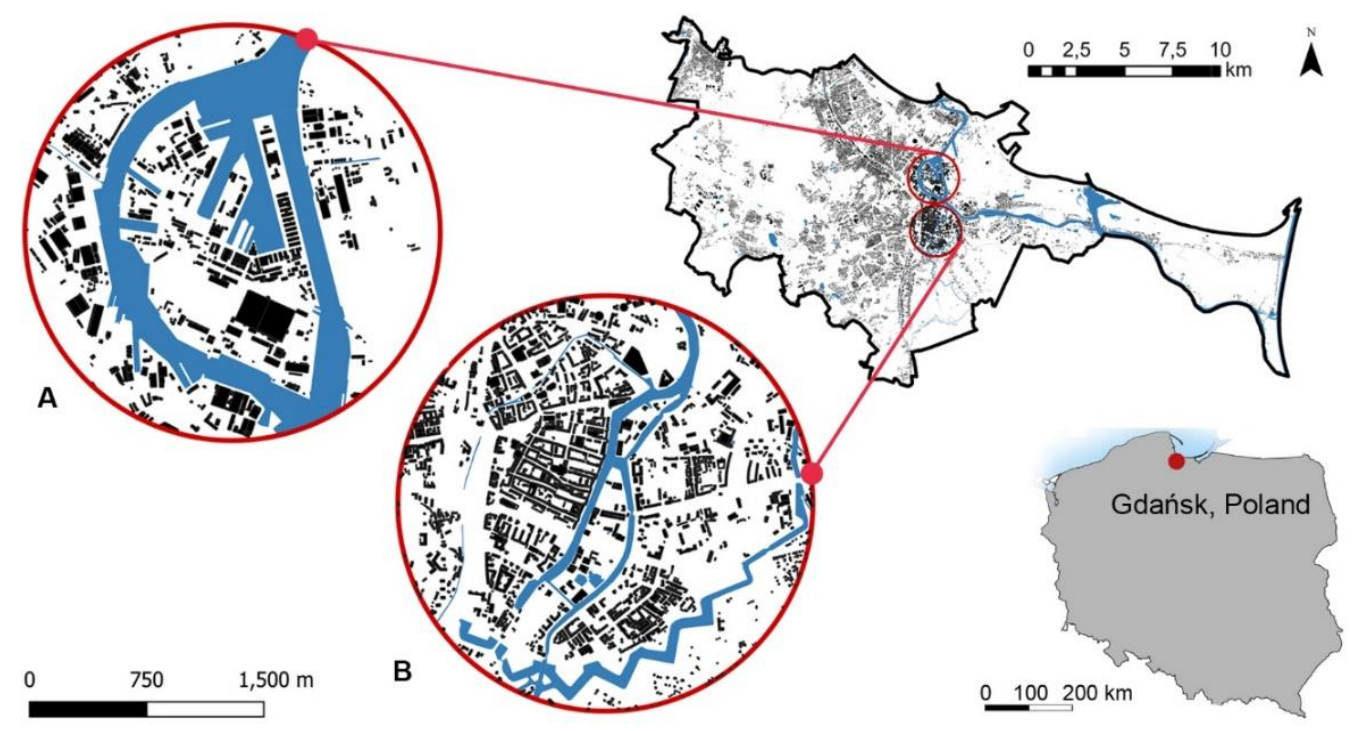

Figure 2. The location and urban fabric of the city of Gdańsk: (A) medium density urban fabric of the historic centre, (B) urban fabric of the port. Own elaboration, data source: [58].

According to Khomenko et al. (2021), Antwerp is one of the cities in Europe with the highest mortality burden due to $\mathrm{NO}_{x}$ pollution [59]. Its high emission levels are mostly related to traffic [60]. Apart from air quality monitoring carried out by the environmental technology agency VITO (2021) [61] which helps in the development of increasingly accurate air quality maps, two major projects also deserve to be mentioned, namely, the City of Things and the social science Curious Noses (CurieuzeNeuzen) project. In the first project, sensors have been collecting a variety of real-time urban data, including air quality parameters [62]. The latter is a project aimed at mapping ambient air quality in Flanders, in which more than 20,000 low-cost measuring devices were located both in cities and in the countryside, and the data were collected by the residents over a period of one month (May 2018) [63]. Subsequently, the obtained data were calibrated with measurements at reference air quality monitoring stations operated by the Flemish Environment Agency (VMM).

From the planning perspective, two main problem areas in Antwerp related to air quality can be named. The first is the very dense urban fabric of the historic centre of Antwerp, with a high proportion of street canyon geometries (compact, high streets flanked by buildings on both sides), which negatively affects the dispersion of pollutants and, therefore, limits them from escaping the increased human exposure areas $[24,64]$. Moreover, the network of busy roads in Antwerp constitutes a problem [23]. Another major source of air pollution is related to industrial activity and to the operation of the Port of Antwerp. However, in the latter case, many measures have been undertaken in the recent years to keep the levels of both land and water emissions below the EU air quality standards [65].

The geographical location of Gdańsk makes it a very interesting case for air quality investigation. It is located by the Gulf of Gdańsk, which provides enhanced air circulation but from the west and south it is enclosed by a moraine plateau $[22,66]$. Moreover, many other local conditions should be taken into consideration as the aero-sanitary state of particular areas is also very strongly affected by their spatial development, land use, or local emission sources such as transportation systems or household fuel combustion. The main air pollution problem in Gdańsk is related to the large number of homes in areas designated for revitalisation which burn coal in the heating season. This applies in particular to the old residential districts. Most council housing is concentrated in these areas and surveys show that as many as $37 \%$ of council units are heated with coal stoves [67]. In Gdańsk, the air quality monitoring is conducted by the Agency of Regional Air Quality Monitoring in the Gdańsk Metropolitan Area (ARMAAG) [68]. 
The air quality status in these cities is partly reflected by its public perception. According to an extensive questionnaire conducted in a study by Van Brussel and Huyse (2019) in seven European cities (with a total of over 7000 completed questionnaires), $78 \%$ of surveyed inhabitants in Antwerp (a representative sample of 1163 responders) were worried about the negative health effects of air pollution. A significant contribution to the increase in the awareness of the issue of air quality was observed due to the previously mentioned citizen science projects. During the implementation of Curious Noses, surveys were conducted at the beginning and at the end of the first phase of the project. They indicated that initially participants took part in the study out of curiosity. At that time, they expected the local air quality in the streets of Antwerp to be moderate (40\%) or bad/very bad (50\%). At the end of the project, $59 \%$ of participants confirmed their views due to the conducted measurements, $27 \%$ reported that local air quality was actually better than they expected, and $11 \%$ claimed the opposite. Moreover, after the implementation of the project, public support for local mitigation measures, such as sustainable mobility measures, increased substantially [69].

In Gdańsk, opinion polls were held in 2016 on a large and representative sample of adult inhabitants, totalling 1500 persons. The results, analysed by Brosz and Załecki (2017), show that the average perception of air quality (on a scale of 1 to 6 , where ' 1 ' stands for 'very poor', and ' 6 ' for 'very good') stood at 3.93, i.e., it was slightly above the average. It is noteworthy that, over the most recent 10 years, this view improved steadily from 3.27 in 2008, 3.37 in 2012, 3.69 in 2014, 3.76 in 2016 to 3.93 in 2018. The subjective perception of air quality differs depending on the home district. It is higher in new districts and residential areas, distant from industrial estates and inhabited mainly by people of higher social and economic status (3.90), and lower in older districts in the vicinities of industrial and storage areas, inhabited mainly by people of lower social and economic position (3.12) [70] (p. 96).

Obviously, the views are not based on any objective data obtained in chemical measurements, but on the subjective experience of the inhabitants themselves. In other words, the air quality framed in this way is not an objective value. It is rather an aggregate of many subjective assessments, each potentially determined by multiple factors, e.g., the needs and expectations with respect to environmental values. This is why, in research practice, one can list some examples testifying to the fact that an objective change of air quality indices (improvement or deterioration) does not always carry a change in the views on the quality expressed in subjective declarations. However, many recent studies also indicate that there is a significant relationship between public perception of the risk associated with exposure to air pollution and the measured or estimated air pollution concentration levels. This may suggest that the knowledge about air pollution is becoming increasingly available to the general public [37]. Therefore, the public discourse on the topic may contribute to the formulation of mitigation and management policies.

\subsection{Methodology}

A qualitative approach was used in order to broaden the scope of the problem area. Both primary and secondary sources were used. The majority of resources were issued by local, regional, or national agencies and administrations but also by social organisations and grassroots movements. These reports deal with environmental protection and focus on controlling, improving, and monitoring air pollution. Alongside desk research of the existing materials, information was collected through individual interviews. Each interview followed the IDI approach (in-depth interview) and was conducted based on a starting-point scenario. Detailed interviews were conducted with a small group of carefully selected individuals who were professionally or socially linked to institutions and organisations involved in management of the natural and built environment. This technique, along with the analysis of reports and planning documents, is an established method for investigating the development of local urban policy aimed at sustainability and environmental improvement, enhancing the understanding of the local social and institutional context of a given problem (see, e.g., [71-73]). 
Fifteen experts were selected based on their involvement in environmental issues, including air pollution-see Table 1. The experts from Gdańsk (10) and Antwerp (5) represented the following professions: urban planning and environmental specialists working in the city administration, specialists working at the air quality monitoring agency, architects, academics, ecologists, and members of local activist groups. Initially the same number of interviews in each city was planned. However, more interviews had to be conducted in Gdańsk due to the fact that the materials collected during the first enquiry proved insufficient to explain the deficiencies in the planning and legal tools in the city. The aim of the interviews was to explore the expert knowledge and the often not commonly known experiences related to various local official and bottom-up actions for urban air quality improvement, in order to identify the stages of public debate on this topic and municipal policy development.

Table 1. The list of local experts and their role.

\begin{tabular}{ccc}
\hline City & Code & Role \\
\hline GD01 & A city official, environmental expert \\
GD02 & Air quality monitoring expert from ARMAAG \\
& GD03 & Architects, founders of a local environmental design studio \\
GD04 & Academic, IT expert \\
& GD05 & Architect, expert from the Ecological Club \\
& GD06 & City official, public space management expert \\
GD07 & Expert from a local district council \\
& GD08 & Expert from a local NGO (Forum for the Development of the \\
& GD09 & Gdańsk Agglomeration-FRAG) \\
& GD10 & City official, environment and agriculture expert \\
Antwerp & AN01 & City official, environmental expert \\
& AN02 & Expert from a local NGO (Ringland) \\
AN03 & City official, urban planning expert \\
& AN04 & Academic, chemist and researcher in social science projects \\
& AN05 & Air quality monitoring expert from Belgian Interregional \\
& Environment Agency (IRCEL) \\
\hline
\end{tabular}

The accumulated material was transcribed and coded. The employed coding model consisted in the basic topical analysis [74]. Techniques derived from the grounded theory methodology (generation of categories, comparison of incidents) were employed at the conclusion-drawing phase in the order recommended by Jean-Claude Kaufmann, (2007) [75]. To process and treat the data, the NVivo software was used (version 9.2), representing software of the CAQDAS type [76]. In qualitative research, environmental discourse concerns specific features of the examined cases and their cultural context. We adopted the assumption that on top of hard empirical data, air quality requires digging down into the events, matters, and phenomena which lie at the heart of the problem.

\section{Results: Interviews with Experts}

\subsection{Air Quality in Public Discourse: Main Issues}

The discursiveness of the presented problem area reveals the structure of the specific knowledge system and the time the discourse takes place in. We wanted to emphasise that in the case of the search for answers to questions related to air quality, discursive practices extend to all levels of this issue. They are present in the institutional sphere, behavioural patterns, common language, and expert statements. These practices are visible in competing concepts related to air quality. They are a part of a wider environmental discourse, an exceptional case among the most important European public debates. They are characterised by greatly differing positions and means of communication between various social and professional groups. Our focus was on the accounts of experts and 
environmental activists due to their participation in actions for building the concept of air quality protection, giving them a status of authoritative figures in this subject matter.

The interviewed experts frequently pointed out that the quality of the air in the city was not a leading problem for many inhabitants, both in Antwerp and in Gdańsk. One of the experts suggested that, when taking into account other problems such as mobility or housing, this issue may not be of the greatest concern. However, it is easier to refer to this problem due to its measurability, which is not always the case with other municipal issues such as liveability <AN03>. Moreover, although general situation in the city might not be very serious according to air quality standards, still some local problems related to city breathability may occur which require specific targeted solutions $<$ GD09 $>$ - and such initiatives, incorporated into municipal policy, spatial development strategies, and social practices, adapted to local conditions and formulated by the environmental or urban planning experts or resulting from bottom-up, social initiatives, were a subject of particular interest in this study.

As one of the experts emphasised, in Antwerp, the problem comes down mostly to traffic pollution $\left(\mathrm{NO}_{2}\right)$ as the other air quality European standards are met $<\mathrm{AN} 05>$. Therefore, it is no wonder that a large part of the heated public debate on air quality concentrates around the pollution from the R1 ring road-a motorway around the city of Antwerp, the construction of which began in 1969 and is currently being completed by the construction of the last segment (the Oosterweel link) [77]. As the urban ring road is located on the former city fortification walls in the centre of the city [78], many residential or commercial investments are located within close proximity. According to one of the interviewed activists, reducing the impact of pollution from the ring road would solve most of the city's air quality problems $<$ AN02 $>$. The available research suggests that converting the entire urban ring road into an underground tunnel is expected to significantly change $\mathrm{PM}_{2.5}$ and $\mathrm{NO}_{2}$ concentration levels and bring health gains for approximately 352,000 inhabitants living within a 1500 metre perimeter around the currently open-air ring road [79]. Additionally, it is recommended to cover the ring road with urban parks (see Figure 3) in order to improve the local air and living quality, while creating new terrains to accommodate the city's increasing population and to finance the construction of the coverage [80]. Although this is considered to be Europe's largest on-going infrastructure project, other issues are also high on the agenda in Antwerp, such as the low-emission zones [81] and tackling pollution accumulation in street canyons within the historical development [60,82].

In Gdańsk, the issue of air quality is also not prioritised even though sociological studies indicate that the natural and landscape values are the very features which make Gdańsk distinguishable from other large cities in Poland [83] (p. 207). Local experts <GD01; GD09> claimed that the air quality is relatively good in Gdańsk in comparison with other Polish cities. However, the stereotype of Gdańsk being a city characterised by good air quality may be an overly far-reaching simplification. Based on recent reports of the local monitoring centre, frequently exceeded standard average daily levels occur in some districts, mostly related to low emissions [84]. This issue seems to be acknowledged not only by city officials and air quality monitoring experts, but also by local designers who see it as a systemic, infrastructural problem $<$ GD03 $>$. Moreover, although not an urgent problem for the time being, traffic pollution may become an increasingly important issue in the near future with the projected increase in traffic and the insufficient development of sustainable mobility programmes [85]. Therefore, air pollution aspects should be raised more often in the public discourse despite the common belief of many inhabitants of Gdańsk that ... "the location on the sea solves all problems, so we need not particularly ponder the situation in the city. Our behaviour, or that of the industry, or transport, or any living activities do not particularly matter, as the wind will blow everything away anyway" <GD08>. 


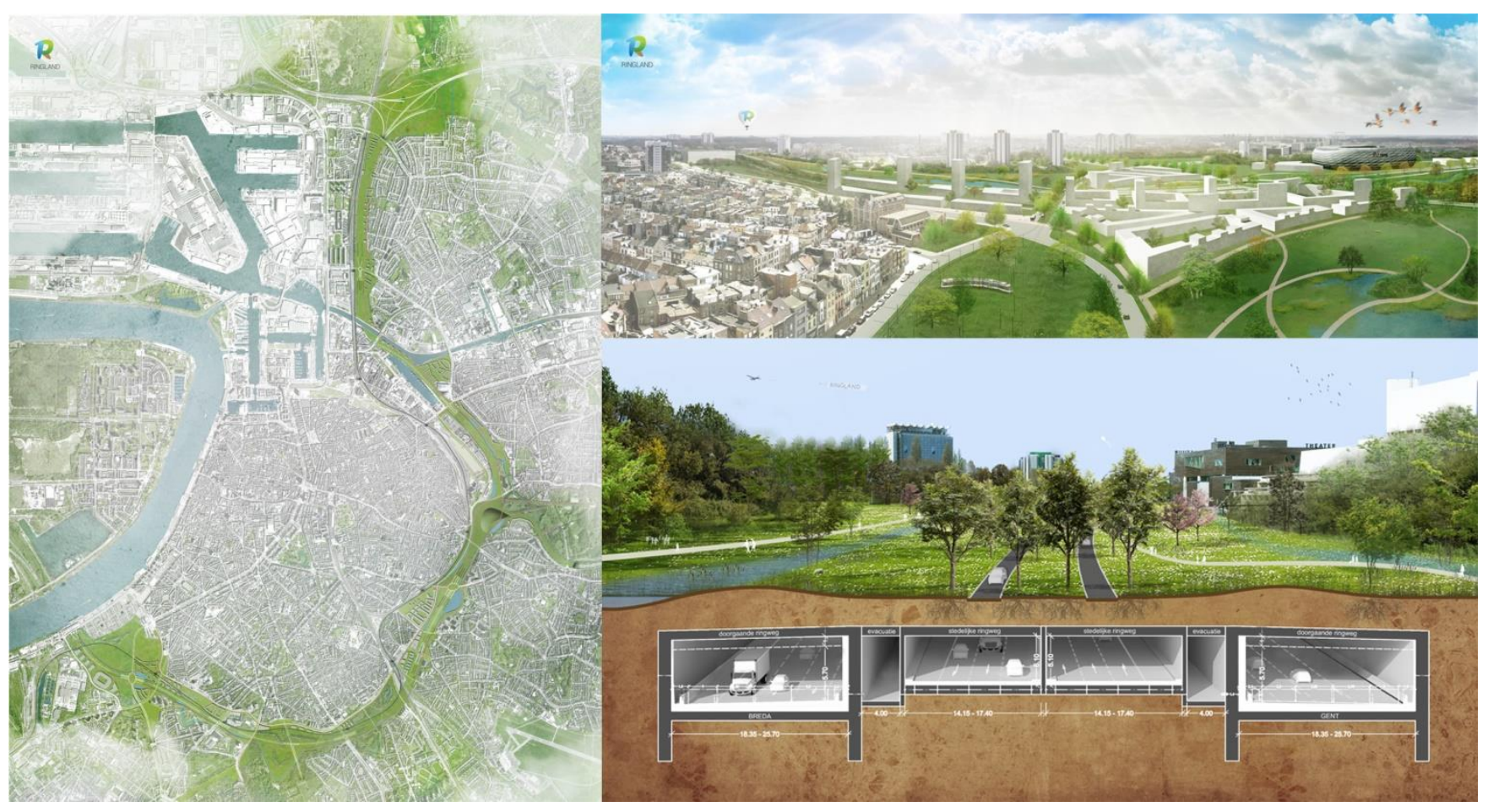

Figure 3. Proposed redevelopment of the ring road system around Antwerp. Source: materials provided by the Ringland association, graphic courtesy of (c) Ringland.

\subsection{Role of Urban Planning and Legal Tools in the Process of Air Quality Improvement}

The issue of urban policy perceived from the perspective of ecological modernisation should involve a search for legal, technical, and urban planning solutions and recognition of the broader context of local economic and social conditions, such as social conflicts and the environmental awareness of the inhabitants. Local governments, however, function within specific legal and organisational frameworks set by the policy of the state implemented in the national dimension. Solving the problem of poor air quality requires harmonious and coordinated cooperation between all actors: the central government, local government, non-governmental organisations, and the citizens themselves.

As the experts in Gdańsk claim, the local government and non-governmental organisations operating in the city often find "their hands tied", as they do not have sufficient legal or financial tools to counteract air pollution effectively $<\mathrm{GD} 01>$. The theme of the insufficiency of the legal tools, the lack of coordination of the actions taken in the area, and the dilution of jurisdiction were mentioned by the experts in Gdańsk fairly often: "In Gdańsk, the monitoring of air quality is good, I would say, but for various reasons, there is no single coordinator, since air is borderless (...) The powers were distributed among various institutions" $<$ GD02 $>$. Similarly, in Antwerp the responsibility for air pollution mitigation measures cannot be assigned to one level of authority. Some issues, such as traffic pollution, are within the competences of not only local, but also regional or even federal government $<$ AN04 $>$. At the local level, some municipal solutions for air quality improvement were already proposed, which will be discussed in the following sections, but it is important to note that their implementation into the practice of spatial development is a different issue. One of the experts notes that, for the time being, these are only planning suggestions and there is no guarantee that they will be implemented in long term planning strategies: "It's still something to discuss and it's still something that is not politically popular" $<$ AN03 $>$.

When asking our experts about the planning and legal tools, project directives, or developmental strategies aimed at improving air quality, we considered it important to learn their opinions on the causes of both achievements and shortfalls in this respect. For 
example, in Antwerp, it is planned to partly tackle the issue of improving air quality through a series of sustainable urban mobility strategies, outlined by the municipal planning office [86]-see Figure 4. They mostly pertain to the city but there is also a large focus on mobility to improve mobility around the port of Antwerp <AN01>. Sustainable mobility is also considered to be an important factor for air quality improvement by local NGOs, but it was pointed out that a modal shift is not only the responsibility of the local or Flemish government, but also of the citizens $<$ AN02 $>$.

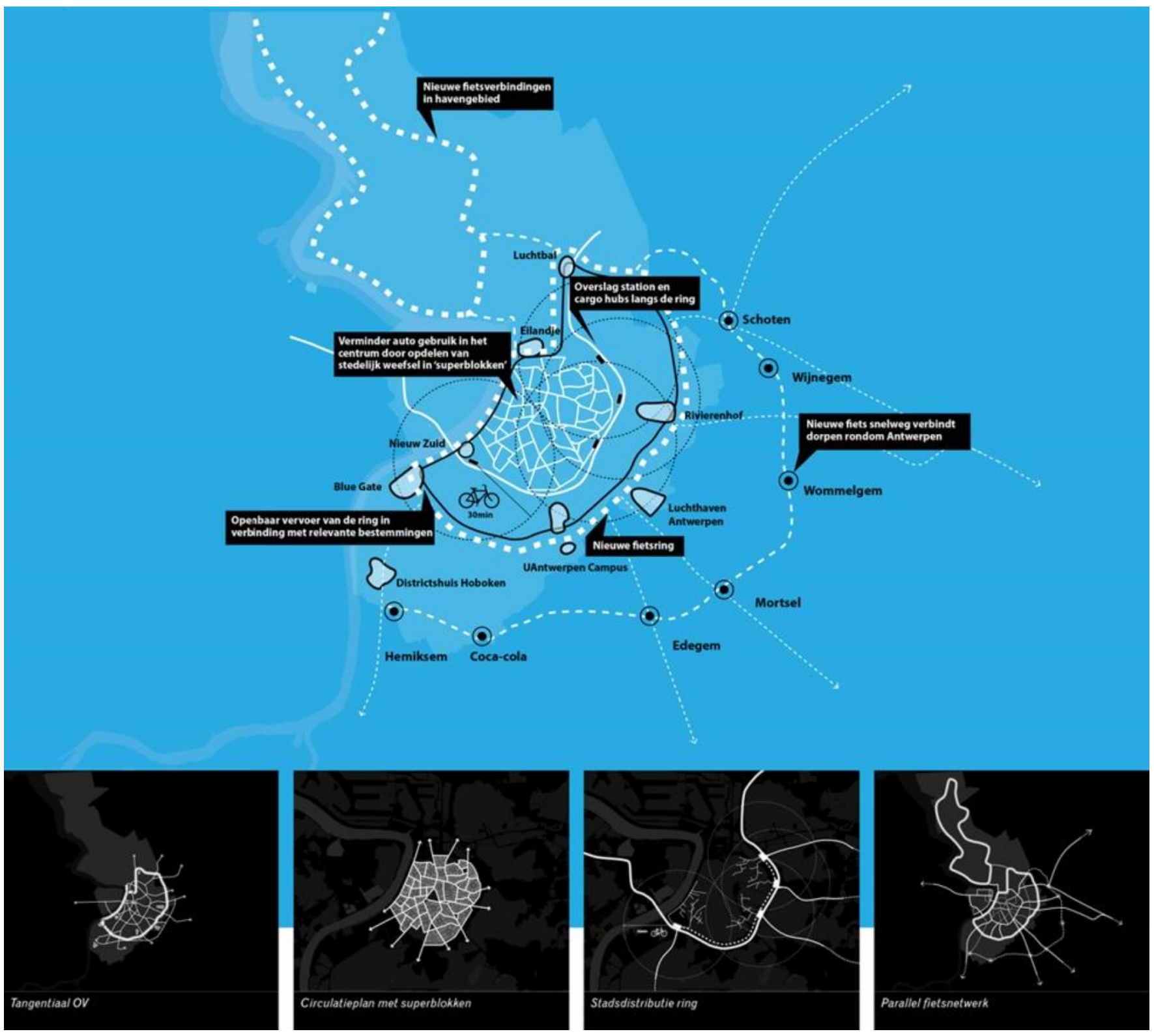

Figure 4. New mobility strategies for the city of Antwerp, aimed at reducing the levels of urban air pollution. Retrieved from: [82], graphic courtesy of one of the authors.

Meanwhile, in Gdańsk, novel solutions in this respect are yet to come as, in the current municipal and regional mobility strategies, the issue of urban air quality is hardly mentioned (see, e.g., the local mobility strategies $[87,88]$ ). For the time being, solutions such as closing shopping malls on Sundays (the Sunday trade ban) seem to be crucial for the reduction of car traffic and, as a result, air quality improvement <GD09>. However, such measures are far from the car traffic restrictions in many European cities. Similarly, 
the issue of air quality and many other environmental aspects in Gdańsk is hardly taken into account in local planning strategies [89].

In case of urban design, one should consider many factors, including local wind conditions. Another interviewee pointed to the problem of the insufficient number of airing corridors in the city $<\mathrm{GD} 02>$. However, designating an urban ventilation strategy is a rather complex issue in which the regional, city, and district levels need to be considered [90]. It also comes down to several design aspects as urban ventilation relies very strongly on the appropriate design of the urban configuration. Several features of the urban structure, such as building arrangements and heights, street orientations, and green infrastructure can improve ventilation in urban areas [24,91]. These features need to be considered with reference to the local conditions and infrastructural parameters.

In Gdańsk this issue is ignored when designing new investments in the city. The expert specialised in air quality monitoring pointed out that she was aware of only one case when environmental and meteorological analysis was considered in planning decisions and that was the case of a water body at a residential estate adapted from the former industrial complex in the Wrzeszcz district. However, in the case of another investment in the same district, a shopping mall, the warnings of air quality monitoring experts that the proposed compact form of the building will block an important ventilation path in the area were not taken into account $<$ GD02 $>$. In Antwerp, as mentioned before, the geometry of the street canyons poses an obstacle to the process of ventilation and pollution dispersion. Therefore, consideration of ventilation conditions should be included in urban design more often, as one of the experts argued $<$ AN01 $>$. Another expert emphasised that enhancing ventilation in the city was a crucial aspect for air quality improvement, especially in locations with the highest pollution concentration levels, so that it can be dispersed $<$ AN05 $>$. The issue of ventilation at the local level was already included in one of the recent developments, as it was mentioned in the interviews, during the development of the Nieuw Zuid estate masterplan $<$ AN01 $>$. The urban grid of the estate, which is located in a close proximity of a busy road, was designed in such a way that the air flow between buildings is facilitated [23,92].

The lack of consideration of air quality and urban ventilation within the process of spatial development in Gdańsk is a result of insufficient planning and legal tools. This issue was raised by, e.g., a city official specialised in public space management and a member of the FRAG association (a local NGO-Forum for the Development of the Gdańsk Agglomeration) <GD06; GD08>. Even if local spatial development plans are developed and some solutions for local air quality improvement are included in them, they are often too general to bring any substantial outcomes. This pertains, for example, to the implementation of road-side vegetation barriers for traffic pollution mitigation as no specific guidelines are available to advise designers, such as the choice of species most efficient in pollution deposition [22]. In Antwerp, on the other hand, many important solutions have already been implemented within the current legal framework, as discussed before, but in the opinion of a local activist $<$ AN02 $>$, there are still many barriers that result from the government's policies on improving car parking and car-accessibility.

One of the interviewees in Gdańsk shared an observation that long-term, multigeneration planning aimed at developing specific pro-environmental habitual ways of using urban space and infrastructure required finding a balance between the freedom of an individual and the effectiveness of actions aimed at improving the quality of the environment. The habit-woven every-day trajectories of using urban space represent the sphere most resistant to remodelling. In sustained development of the city, the fundamental tool in building the city's strategy with respect to designing a cohesive urban planning system, which would recognise the values of the natural environment, is the general plan. Local plans tend to tear urban structure apart and fragment it. Moreover, their impact is spatially limited. Apart from that, the city needs a development vision which is based on common environmental values $<$ GD05 $>$. 
In Flanders, the spatial development policy is also a significant issue related to air quality, especially in relation to a lack of compact urban development. On the one hand, as discussed in case of some local investments, compact, high-density urban areas are associated with a local decrease in ventilation efficiency [21]. On the other hand, at the city scale, more compact urban form may result in less air pollution emissions, e.g., due to reduced travelling distances and decreased automobile dependence [93]. However, this relationship is very complex and need to be carefully considered in urban planning [94]. As one of the experts on air quality stated, "in Flanders there is a historical issue resulting from ribbon developments along major roads and nowadays as well people tend to choose residential locations far from their work, adding to the increase in traffic" <AN04>. Another expert also elaborated on this issue: "we didn't have good spatial planning. Everyone could build their own home when they wanted and that's why we have so many laws and so much urban sprawl (...) You can now try to improve that a bit but the major problem is a historical issue" $<$ AN05 $>$.

Another issue that should be discussed in this context which was often mentioned in the interviews is the development of the urban greenery system. The statements of the designers from Gdańsk show that the problem is not fully understood: "of course, designating land for greenery is very important when planning roads, and public greens, parks, squares, or pocket parks, all of which substantially improve the situation" <GD03 $>$. Looking at the statement of another expert, it seems that greenery is advocated as a major planning solution for air quality improvement <GD09>. However, as much as urban greenery may generate numerous microclimatic or social benefits, reducing noise, regulating the thermal environment, supporting water management, promoting biodiversity, or improving and providing ecosystem services for the inhabitants [95-98], its positive impact on air quality is not always that straightforward. On the contrary, in some scenarios, greenery in urban areas can bring an opposite effect. This may be the case, for example, of not properly designed roadside vegetation barriers or high greenery in street canyons [24,99]. Moreover, high vegetation may obstruct the process of urban ventilation and should also be considered in the ventilation strategies alongside the effect of the built-up structures [23].

In Antwerp, these findings seem to be more widespread as, for example, designers can familiarise themselves with a special document created by the Department of Environment in Flanders [100], which indicates the impact of the location and parameters of roadside vegetation and green walls (among other design elements and parameters) in street canyons on the reduction of pollution levels. This assignment was commissioned by the local authorities: "it's a piece of research we ordered to know more about these things but at the street level. We wanted to have some design options when we really have to renew the streets" <AN03>. According to this report, in many cases urban greenery, e.g., in street canyons and near open roads, can be very carefully planted. This issue was indeed discussed by one of the experts in Antwerp: "we are aware that we will not use green in busy streets for now just to improve air quality because it has been pointed out by Vito several times that it doesn't measurably increase air quality" <AN01>. Similar guides for the design of an urban vegetation system for air quality improvement have been published in other cities-e.g., in London [101]. Unfortunately in Gdańsk there are no such guidelines for designers which would account for local climatic, weather or infrastructural conditions, the availability of species, or even budgetary limitations [22].

In the interviews in Gdańsk, some of the experts also focussed on solutions comprising the entire system of heating houses and flats, which is, as mentioned before, one of the main issues related to air quality in the city. As they see it, the policy pursued by the city in this respect should aim at setting limits for non-environmentally friendly and energy-consuming solutions: ". . that is why I believe that designation of new areas for development should be pre-conditioned by providing access to the city's heating system $"<$ GD10 $>$. It is also important to introduce legal solutions regulating the type of fuels which can be used in boilers and household hearths, or investments in public transport "... if there is no other transport available than private cars, this affects the quality of air in all 
locations crossed by the roads leading to one's destination. As far as heating is concerned, my opinion on what is currently done in this respect is unfortunately negative. We are only interested in what is delimited by our own fence. What we need are solutions at the level of resolutions by the City Council, or regulations issued by the City Hall" <GD07> .

Finally, when discussing urban policies for air quality improvement, environmental participation and the involvement of various social groups should be also considered. In Antwerp, the postulates of the local NGOs and bottom-up organisations are increasingly often taken into account, as their representative pointed out. At the beginning, there was a lot of resistance in terms of the cooperation between the administration and local activists, but it began improving, stated a local activist related to the Ringland initiative $<$ AN02 $>$. A similar view was also shared by one of the city officials, who noted that in the past few years civil society has become increasingly involved in the process of decision making $<$ AN03>. It also seems, based on the evidence from the social science projects run in the city, that there is growing awareness of the issue of air quality. In Gdańsk, a much more modest initiative related to social air quality monitoring has been carried out so far, in which several dozen low-cost air quality monitoring sensors were handed out to the inhabitants. However, as one of the experts claimed, it could be already noticed that participation in air quality monitoring seems to be an important factor determining social engagement. Otherwise, the general interest in the issue would be very limited $<$ GD04 $>$.

\section{Discussion and Conclusions}

The public debate and policy development on the topic of air quality was discussed from the point of view of the local institutional and bottom-up approaches and on the local experts' thoughts on the experiencing and managing of air quality. This allowed for modelling the dimensions of the debate and policy development and identifying its key characteristics. The features include: (1) the level of the media debate, (2) the level of cooperation between the academics and institutions in developing research-based policy, (3) the perception of the public debate, also connected with the involvement of local communities, and, finally, (4) the institutional background and the level of politicisation of air quality management. Four levels of the development of urban air quality policy and debate were identified and the cities of Antwerp and Gdańsk were placed on that scale based on the analysed statements of the local experts and the available secondary materials.

In the illustration above (Figure 5) we showed the process of development of the public debate and urban policy regarding the issue of urban air quality and the key characteristics of each stage. The scheme contains four phases. The initial one denotes a lack of urban policy and debate, followed by the emerging and advanced policy and debate, and ending with fully developed urban air quality policy and debate. According to the conducted study, we concluded that the situation in Gdańsk was aptly described by the pre-emerging phase of the process. At this point, we observe the characteristics of the initial and subsequent phases. In turn, the situation in Antwerp was more accurate to indicate the phase between the emerging politics and debate in general and shaping the occurrence of its advanced form.

The issue of air quality, as the study revealed, is linked to a specific group of subjects, or actors, stakeholders (central institutions, non-governmental organisations, entrepreneurs, and inhabitants), communication channels (traditional and electronic media), and strategies in action (law-making, creating local policies, carrying out specific projects). When the inhabitants come across individual elements of the discourse in their daily lives, they turn their attention to the issue of air quality. Air, the central element of the discourse, just like the space we live in, remains a thing we experience without giving it a thought, and as such it calls for a reflective point of view.

As the experts see it, the knowledge of the air quality issue and smog, as well as actions taken to improve the situation, are still far from satisfactory. The model dimension of the interview analysis adopted in the analysis enables identification and pinpointing of the features of the actions within the discourse, from grassroots initiatives to actions imposed along the administrative line. Being at different stages of translation into tangible 
actions, they are hard to map precisely. According to the experts, the actions pursued in the city space are of tactical nature, focussed on the medium-term perspective covering several years.

The development of urban air quality policy and debate

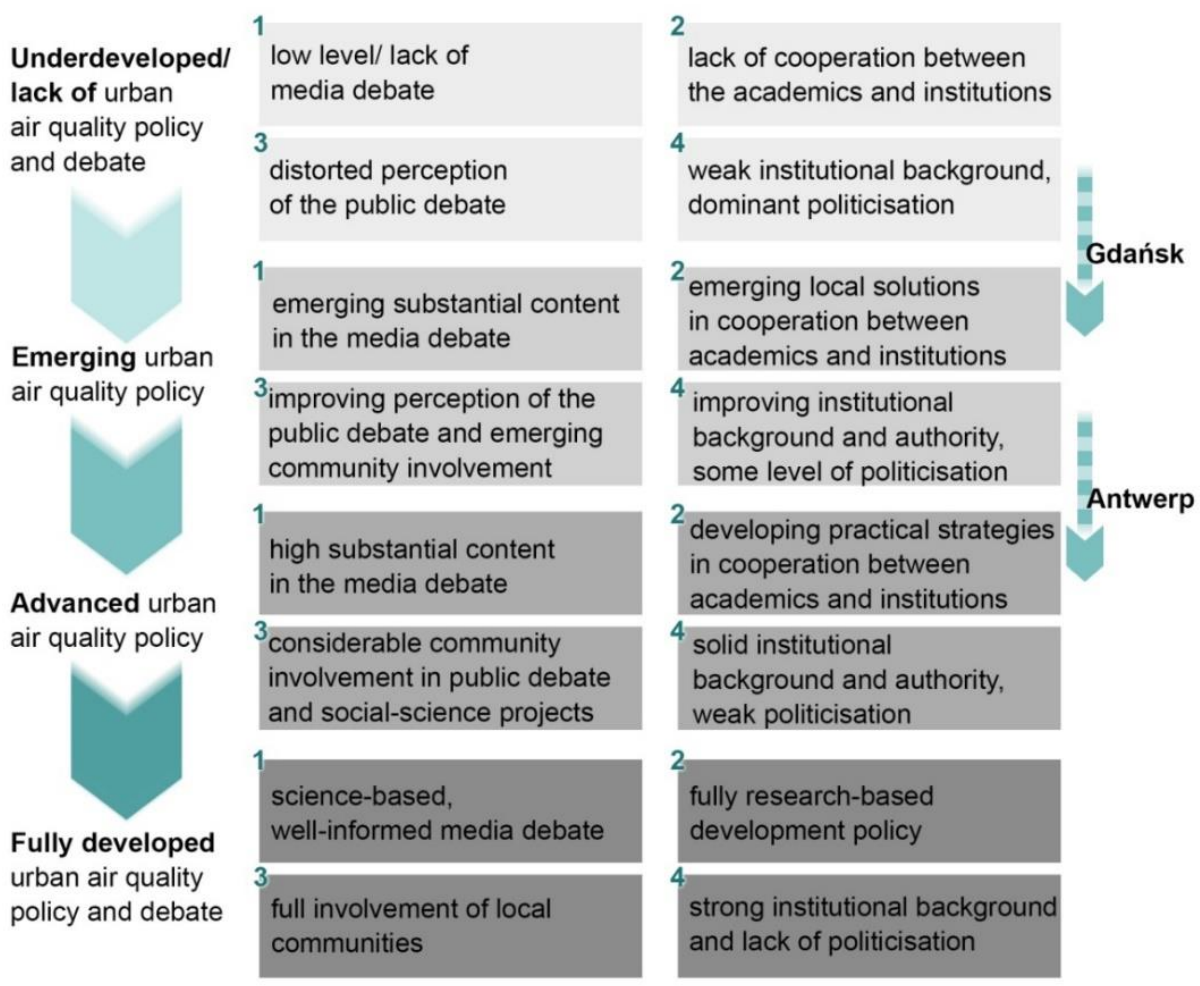

Figure 5. The qualitative density of development of the public debate and urban policy regarding the issue of urban air quality.

Based on the accumulated material, one may expect growth in the dynamics and temperature of the discussion on air pollution in the context of broader phenomena and social/cultural and civilisation-related change factors. The public discourse related to the quality of air will develop towards interdisciplinary studies based on knowledge and data originating from different disciplines (natural sciences, technology, environmental sciences, and social studies).

The problem of air pollution remains a subject of research and discussion at the global and local levels. Perceived from the local perspective, i.e., that of Antwerp/Gdańsk, despite the differences stemming from history and culture, the problem involves the development and improvement of the planning tools used to reduce air pollution. The priorities on which the two cities focus are modernisation of consumption at the level of daily practice by supplying new models of behaviour correlated with spatial solutions. As it turns out, adoption of cultural and technological determinism as the fundamental change factor is insufficient. It is necessary to develop mental tools consisting in the building of a correlation between the technosphere and the world of values, the latter of which still remain marginal today. Although the last decades brought some changes in the way people perceive the relation between nature and the built environment, it still should be considered a priority to broaden environmental awareness and to activate various social groups to commit to the values and ideas of sustainable development. If environmental problems are to better understood, the researchers from various disciplines need to cooperate even more closely.

From a longer time perspective, eco-dictatorship reflected in, e.g., restricting flights, eliminating cars powered with fossil fuels, forbidding the sale of beef even before its affordable substitutes are available, or high $\mathrm{CO}_{2}$ taxes, etc., will not bring the expected results in the long run, unless they are accompanied by changes in social awareness. The 
disintegration of the environmental and natural processes in urban areas, accelerated by industry, triggers powerful social energy, bringing a new dimension to the relations between nature and the society and opening new future perspectives, in which nature is part of the built environment.

Author Contributions: Conceptualisation, J.B., M.D., J.Z., M.B., D.V. and M.V.A.; methodology, J.B., M.D., J.Z., M.B., D.V. and M.V.A.; investigation, J.B., M.D., J.Z., M.B., D.V. and M.V.A.; resources, J.B., M.D., J.Z., M.B., D.V. and M.V.A.; writing—original draft preparation, J.B., M.D., J.Z., M.B., D.V. and M.V.A.; writing—review and editing, J.B., M.D., J.Z., M.B., D.V. and M.V.A. visualization, J.B., M.D., J.Z., M.B., D.V. and M.V.A. All authors have read and agreed to the published version of the manuscript.

Funding: This work was funded by statutory funds of the Gdańsk University of Technology, Faculty of Architecture, Poland and Special Research Fund (BOF) provided by the Flemish Government and the University of Antwerp, Belgium, Doctoral project ID: 37035.

Institutional Review Board Statement: Not applicable.

Informed Consent Statement: Informed consent was obtained from all participants involved in the study.

Data Availability Statement: The relevant data underlying this study are either fully available under the details provided in the references or, in case of the in-depth interviews, are not publicly available as they contain information that could compromise the privacy of our interviewees. For further questions please contact the corresponding author.

Acknowledgments: The authors gratefully acknowledge the support from the participants of the in-depth interviews.

Conflicts of Interest: The authors declare no conflict of interest.

\section{References}

1. Beck, U. World Risk Society; Polity Press: Cambridge, UK, 1999.

2. Beck, U.; Giddens, A.; Lash, S. (Eds.) Reflexive Modernization. Politics, Tradition and Aesthetics in the Modern Social Order; Polity Press: Cambridge, UK, 1995.

3. Boström, M.; Lidskog, R.; Uggla, Y. A reflexive look at reflexivity in environmental sociology. Environ. Sociol. 2017, 3, 6-16. [CrossRef]

4. Van Asselt, M.B.A.; Van Bree, L. Uncertainty, precaution and risk governance. J. Risk Res. 2011, 14, 401-408. [CrossRef]

5. Rootes, C. Globalisation, environmentalism and the global justice movement. Environ. Polit. 2005, 14, 692-696. [CrossRef]

6. Dobson, A.; Bell, D. (Eds.) Environmental Citizenship; MIT Press: Cambridge, MA, USA, 2006.

7. Jucu, I.S. Recent issues of spatial restructuring in Romanian medium-sized towns: Spatial conversion and local urban regeneration. In Proceedings of the 16th International Multidisciplinary Scientific GeoConference SGEM, Albena, Bulgaria, 30 June-6 July 2016; Volume 3, pp. 493-500.

8. Bush, J.; Doyon, A. Building urban resilience with nature-based solutions: How can urban planning contribute? Cities 2019, 95, 102483. [CrossRef]

9. Lopes, H.S.; Remoaldo, P.C.; Ribeiro, V.; Martín-Vide, J. Perceptions of human thermal comfort in an urban tourism destination-A case study of Porto (Portugal). Build. Environ. 2021, 205, 108246. [CrossRef]

10. Lopes, H.; Remoaldo, P.; Silva, M.; Ribeiro, V.; Martín Vide, J. Climate in tourism's research agenda: Future directions based on literature review. Boletín Asoc. Geógrafos Españoles 2021, 90, 1-58. [CrossRef]

11. Paterson, M.; Stripple, J. My Space: Governing Individuals' Carbon Emissions. Environ. Plan. D Soc. Space 2010, 28, 341-362. [CrossRef]

12. Eelderink, M.; Vervoort, J.M.; van Laerhoven, F. Using participatory action research to operationalize critical systems thinking in social-ecological systems. Ecol. Soc. 2020, 25, 16. [CrossRef]

13. Ungar, M.; McRuer, J.; Liu, X.; Theron, L.; Blais, D.; Schnurr, M.A. Social-ecological resilience through a biocultural lens: A participatory methodology to support global targets and local priorities. Ecol. Soc. 2020, 25, 8. [CrossRef]

14. Jans, L. Changing environmental behaviour from the bottom up: The formation of pro-environmental social identities. J. Environ. Psychol. 2021, 73, 101531. [CrossRef]

15. Bulkeley, H.; Betstill, M. Cities and Climate Change: Urban Sustainability and Global Environmental Governance, 1st ed.; Routledge: London, UK, 2003.

16. Giddens, A. Modernity and Self-Identity: Self and Society in the Late Modern Age; Polity Press: Cambridge, UK, 1991.

17. Ulrich, B. World at Risk: The New Task of Critical Theory. Dev. Soc. 2008, 37, 1-21.

18. Knaggård, Å.; Ness, B.; Harnesk, D. Finding an academic space: Reflexivity among sustainability researchers. Ecol. Soc. 2018, 23, 20. [CrossRef] 
19. Caravaggio, N.; Caravella, S.; Ishizaka, A.; Resce, G. Beyond $\mathrm{CO}_{2}$ : A multi-criteria analysis of air pollution in Europe. J. Clean. Prod. 2019, 219, 576-586. [CrossRef]

20. Air Pollution. Available online: https://www.eea.europa.eu/themes/air/intro (accessed on 1 July 2020).

21. He, B.-J.; Ding, L.; Prasad, D. Enhancing urban ventilation performance through the development of precinct ventilation zones: A case study based on the Greater Sydney, Australia. Sustain. Cities Soc. 2019, 47, 101472. [CrossRef]

22. Badach, J.; Dymnicka, M.; Baranowski, A. Urban vegetation in air quality management: A review and policy framework. Sustainability 2020, 12, 1258. [CrossRef]

23. Badach, J.; Voordeckers, D.; Nyka, L.; Van Acker, M. A framework for Air Quality Management Zones-Useful GIS-based tool for urban planning: Case studies in Antwerp and Gdańsk. Build. Environ. 2020, 174, 106743. [CrossRef]

24. Voordeckers, D.; Lauriks, T.; Denys, S.; Billen, P.; Tytgat, T.; Van Acker, M. Guidelines for passive control of traffic-related air pollution in street canyons: An overview for urban planning. Landsc. Urban Plan. 2021, 207, 103980. [CrossRef]

25. Blocken, B.; Tominaga, Y.; Stathopoulos, T. CFD simulation of micro-scale pollutant dispersion in the built environment. Build. Environ. 2013, 64, 225-230. [CrossRef]

26. $\mathrm{Ng}$, E. Policies and technical guidelines for urban planning of high-density cities-Air ventilation assessment (AVA) of Hong Kong. Build. Environ. 2009, 44, 1478-1488. [CrossRef]

27. City of London. Wind Microclimate Guidelines for Developments in the City of London; City of London: London, UK, 2019.

28. Yuan, C.; Ng, E.; Norford, L.K. Improving air quality in high-density cities by understanding the relationship between air pollutant dispersion and urban morphologies. Build. Environ. 2014, 71, 245-258. [CrossRef] [PubMed]

29. Beaudoin, J.; Farzin, Y.H.; Lin Lawell, C.-Y.C. Public transit investment and sustainable transportation: A review of studies of transit's impact on traffic congestion and air quality. Res. Transp. Econ. 2015, 52, 15-22. [CrossRef]

30. Niehoff, N.; von Schneidemesser, E.; Schmitz, S.; Schwartzbach, F.; Becker, S.; Weiand, L. An assessment of perceptions of air quality surrounding the implementation of a traffic-reduction measure in a local urban environment. Sustain. Cities Soc. 2018, 41, 525-537.

31. Pisoni, E.; Christidis, P.; Thunis, P.; Trombetti, M. Evaluating the impact of "Sustainable Urban Mobility Plans" on urban background air quality. J. Environ. Manag. 2019, 231, 249-255. [CrossRef]

32. Transport for London. Low Emission Neighbourhoods: Guidance Note; Transport for London: London, UK, 2019.

33. Valencia, A.R.Z.; Umaña, M.R.; Wences, H.J.A.; Rosales, A.A.R.; Alviso, C.R.; González, J.G. The air quality perception of residents in the metropolitan zone of acapulco who live around intersections with intense traffic. Environments 2020, 7, 21. [CrossRef]

34. Lou, B.; Barbieri, D.M.; Passavanti, M.; Hui, C.; Gupta, A.; Hoff, I.; Lessa, D.A.; Sikka, G.; Chang, K.; Fang, K.; et al. Air pollution perception in ten countries during the COVID-19 pandemic. Ambio 2021, 1-15. [CrossRef]

35. Huang, L.; Rao, C.; van der Kuijp, T.J.; Bi, J.; Liu, Y. A comparison of individual exposure, perception, and acceptable levels of PM 2.5 with air pollution policy objectives in China. Environ. Res. 2017, 157, 78-86. [CrossRef]

36. Oltra, C.; Sala, R.; López-asensio, S.; Germán, S.; Boso, À. Individual-level determinants of the public acceptance of policy measures to improve urban air quality: The case of the barcelona low emission zone. Sustainability 2021, 13, 1168. [CrossRef]

37. Cori, L.; Donzelli, G.; Gorini, F.; Bianchi, F.; Curzio, O. Risk perception of air pollution: A systematic review focused on particulate matter exposure. Int. J. Environ. Res. Public Health 2020, 17, 6424. [CrossRef] [PubMed]

38. Brimblecombe, P.; Zong, H. Citizen perception of APEC blue and air pollution management. Atmos. Environ. 2019, $214,116853$. [CrossRef]

39. Schmitz, S.; Becker, S.; Weiand, L.; Niehoff, N.; Schwartzbach, F.; von Schneidemesser, E. Determinants of public acceptance for traffic-reducing policies to improve urban air quality. Sustainability 2019, 11, 3991. [CrossRef]

40. Hodgson, A.; Hitchings, R. Urban air pollution perception through the experience of social practices: Talking about breathing with recreational runners in London. Health Place 2018, 53, 26-33. [CrossRef] [PubMed]

41. Nedovic-Budic, Z.; Knaap, G.J.; Shahumyan, H.; Williams, B.; Slaev, A. Measuring urban form at community scale: Case study of Dublin, Ireland. Cities 2016, 55, 148-164. [CrossRef]

42. Hooftman, N.; Oliveira, L.; Messagie, M.; Coosemans, T.; Van Mierlo, J. Environmental analysis of petrol, diesel and electric passenger cars in a Belgian urban setting. Energies 2016, 9, 84. [CrossRef]

43. Menut, L.; Bessagnet, B.; Siour, G.; Mailler, S.; Pennel, R.; Cholakian, A. Impact of lockdown measures to combat Covid-19 on air quality over western Europe. Sci. Total Environ. 2020, 741, 140426. [CrossRef]

44. World Health Organization WHO Global Urban Ambient Air Pollution Database. Available online: https://www.who.int/ airpollution/data/cities/en/ (accessed on 1 January 2018).

45. Court of Justice of the European Union. Judgement in Case C-336/16; Court of Justice of the European Union: Luxembourg, 2018.

46. Łowicki, D. Landscape pattern as an indicator of urban air pollution of particulate matter in Poland. Ecol. Indic. 2019, 97, 17-24. [CrossRef]

47. Maione, M.; Mocca, E.; Eisfeld, K.; Kazepov, Y.; Fuzzi, S. Public perception of air pollution sources across Europe. Ambio 2020, 50, 1150-1158. [CrossRef]

48. Hannigan, J. Environmental Sociology: A Social Constructionist Perspective; Routledge: New York, NY, USA, 2006.

49. Bell, M.M. An Invitation to Environmental Sociology, 2nd ed.; Pine Forge Press: Thousand Oaks, CA, USA, 2004.

50. Beck, U. Ecological Politics in an Age of Risk; Polity Press: Cambridge, UK, 2002.

51. Bell, D.R. Liberal Environmental Citizenship. Environ. Polit. 2005, 14, 179-194. [CrossRef] 
52. Sterkx, S. Antwerp. In Cities as Engines of Sustainable Competitiveness: European Urban Policy in Practice; Van den Berg, L., Van der Meer, J., Carvalho, L., Eds.; Routledge Taylor \& Francis Group: Abingdon-on-Thames, UK, 2016; pp. 85-104.

53. Tölle, A. Gdańsk. Cities 2008, 25, 107-119. [CrossRef]

54. Dymnicka, M.; Szczepański, J. Dilemmas of Identity in Contemporary Cities. The City of Gdansk as an Example. Procedia Eng. 2016, 161, 1225-1229. [CrossRef]

55. Bouzarovski, S. Building Events in Inner-City Gdańsk, Poland: Exploring the Sociospatial Construction of Agency in Built Form. Environ. Plan. D Soc. Space 2009, 27, 840-858. [CrossRef]

56. Lorens, P.; Bugalski, Ł. Reshaping the Gdańsk Shipyard-The Birthplace of the Solidarity Movement. The Complexity of Adaptive Reuse in the Heritage Context. Sustainability 2021, 13, 7183. [CrossRef]

57. Departement Omgeving Data Ondergrond Vlaanderen. Available online: www.dov.vlaanderen.be/ (accessed on 1 March 2019). (In Flemish).

58. Head Office of Geodesy and Cartography General Geographic Database. Available online: http://www.gugik.gov.pl/stronaglowna (accessed on 1 April 2019). (In Polish)

59. Khomenko, S.; Cirach, M.; Pereira-Barboza, E.; Mueller, N.; Barrera-Gómez, J.; Rojas-Rueda, D.; de Hoogh, K.; Hoek, G.; Nieuwenhuijsen, M. Premature mortality due to air pollution in European cities: A health impact assessment. Lancet Planet. Health 2021, 5, 121-134. [CrossRef]

60. Nikolova, I.; Janssen, S.; Vos, P.; Vrancken, K.; Mishra, V.; Berghmans, P. Dispersion modelling of traffic induced ultrafine particles in a street canyon in Antwerp, Belgium and comparison with observations. Sci. Total Environ. 2011, 412, 336-343. [CrossRef] [PubMed]

61. VITO ATMO-STREET Mapping Air Quality to Street Level. Available online: https://vito.be/en/atmo-street (accessed on 20 April 2021).

62. Braem, B.; Latré, S.; Leroux, P.; Demeester, P.; Coenen, T.; Ballon, P. Designing a smart city playground: Real-time air quality measurements and visualization in the City of Things testbed. In Proceedings of the IEEE 2nd International Smart Cities Confeference: Improving Citizens Quality of Life, ISC2, Trento, Italy, 11-15 September 2016; pp. 1-2.

63. De Craemer, S.; Vercauteren, J.; Fierens, F.; Lefebvre, W.; Meysman, F.J.R. Using Large-Scale NO2 Data from Citizen Science for Air-Quality Compliance and Policy Support. Environ. Sci. Technol. 2020, 54, 11070-11078. [CrossRef] [PubMed]

64. Voordeckers, D.; Meysman, F.J.R.; Billen, P.; Tytgat, T.; Van Acker, M. The impact of street canyon morphology and traffic volume on NO2 values in the street canyons of Antwerp. Build. Environ. 2021, 197, 107825. [CrossRef]

65. Port of Antwerp. Air quality. Available online: https://www.portofantwerp.com/en (accessed on 5 January 2021).

66. Gdańsk Development Office. The Study on Conditions and Spatial Development Directions for Gdańsk; Gdańsk Development Office: Gdańsk, Poland, 2018. (In Polish)

67. Tobis, T.; Brosz, M. Publicly-Owned Apartments Tenants Satisfaction Survey. A Study Report; Gdańsk City Hall: Gdańsk, Poland, 2018. (In Polish)

68. ARMAAG Foundation. Available online: http://armaag.gda.pl/en/index.htm (accessed on 5 January 2021).

69. Van Brussel, S.; Huyse, H. Citizen science on speed? Realising the triple objective of scientific rigour, policy influence and deep citizen engagement in a large-scale citizen science project on ambient air quality in Antwerp. J. Environ. Plan. Manag. 2019, 62, 534-551. [CrossRef]

70. Brosz, M.; Załęcki, J. The Quality of Life in Gdańsk and Its Social and Spatial Conditions; Wydawnictwo Zakładu Realizacji Badań Społecznych Q\&Q: Przodkowo, Poland, 2017. (In Polish)

71. Grandin, J.; Haarstad, H. Transformation as relational mobilisation: The networked geography of Addis Ababa's sustainable transport interventions. Environ. Plan. D Soc. Space 2021, 39, 289-308. [CrossRef]

72. Tim, Y.; Pan, S.L.; Bahri, S.; Fauzi, A. Digitally enabled affordances for community-driven environmental movement in rural Malaysia. Inf. Syst. J. 2018, 28, 48-75. [CrossRef]

73. Yukalang, N.; Clarke, B.; Ross, K. Barriers to Effective Municipal Solid Waste Management in a Rapidly Urbanizing Area in Thailand. Int. J. Environ. Res. Public Health 2017, 14, 1013. [CrossRef]

74. Charmaz, K. Constructing Grounded Theory; SAGE Publications: Thousand Oaks, CA, USA, 2006.

75. Kaufmann, J.-C. L'Entretien Compréhensif, 2nd ed.; Armand Colin: Paris, France, 2007.

76. Woolf, N.H.; Silver, C. Qualitative Analysis Using NVivo: The Five-Level QDA ${ }^{\circledR}$ Method; Routledge: New York, NY, USA, 2017.

77. The Oosterweel link. Available online: https://www.oosterweelverbinding.be/oosterweel-link (accessed on 30 December 2020).

78. Van Acker, M. From Flux to Frame; Leuven University Press: Leuven, Belgium, 2014.

79. Van Brusselen, D.; Arrazola de Oñate, W.; Maiheu, B.; Vranckx, S.; Lefebvre, W.; Janssen, S.; Nawrot, T.S.; Nemery, B.; Avonts, D. Health Impact Assessment of a Predicted Air Quality Change by Moving Traffic from an Urban Ring Road into a Tunnel. The Case of Antwerp, Belgium. PLoS ONE 2016, 11, e0154052. [CrossRef]

80. D’Hooghe, A.; Blondia, M.; Peeters, S.; van der Leeuw, R.; Burquel, B.; Duré, M.; Rogiers, H.; Noë, G.; Boddeke, D.; van Oosten, M.; et al. Over de Ring: Samen naar een Aantrekkelijke Metropool: Kompas voor een Ambitieuze Stadsregionale Transformatie door Overkappingen en Leefkwaliteitsprojecten voor de Antwerpse Regio; Team van de Intendant voor de overkapping van de Antwerpse Ring: Antwerp, Belgium, 2016.

81. Smart Ways to Antwerp Low Emission Zone. Available online: https://www.slimnaarantwerpen.be/en/LEZ (accessed on 2 June 2021). 
82. Frijters, E.; Klijn, O.; Driessen, B.; Vetrugno, C.; Zhang, H.; Vietti, M.; Chow, M.; Barker, M.; Kushi, M.; Kellezi, U.; et al. Metabolism of Antwerp: The City of Flows; Final report; FABRICations, Universiteit Antwerpen, marco.broekman, Common Ground: Antwerp, Belgium, 2018. (In Flemish)

83. Załęcki, J. Gdańsk from a Sociological Point of View; University of Gdańsk Press: Gdańsk, Poland, 2020. (In Polish)

84. Bielawska, M.; Zgoda, D.; Szymanska, K. The State of Atmospheric Pollution I the Tri-City Agglomeration in 2018 and the Report on the Activities of ARMAAG Foundation; ARMAAG Foundation: Gdańsk, Poland, 2019. (In Polish)

85. Badach, J. The Potential of Improving Air Quality by Urban Mobility Management: Policy Guidelines and a Case Study. In Proceedings of the 10th International Conference on Future Environment and Energy, Kyoto, Japan, 7-9 January 2020; Volume 581.

86. Bergers, J.; Van Acker, M. Het stedelijk metabolisme van Antwerpen. AGORA Mag. 2018, 34, 8-11. [CrossRef]

87. Michalski, L.; Jamroz, K.; Grzelec, K.; Grulkowski, S.; Kaszubowski, D.; Okraszewska, R.; Birr, K.; Kustra, W. Strategy for Transport and Mobility for the Metropolitan Area: Gdańsk, Sopot and Gdynia STiM 2030; Gdansk Metropolitan Area Association: Gdańsk, Poland, 2015. (In Polish)

88. Andrzejczak, M.; Budziński, Ł.; Budziszewski, T.; Chomicz, A.; Ejsmont, R.; Hoppe, M.; Hrynkiewicz, M.; Kitliński, R.; KozubLewna, A.; Krajewski, G.; et al. Sustainable Urban Mobility Plan (SUMP) for the City of Gdańsk 2030; Grafpol: Wrocław, Poland, 2018. (In Polish)

89. Badach, J.; Kolasińska, P.; Paciorek, M.; Wojnowski, W.; Dymerski, T.; Gębicki, J.; Dymnicka, M.; Namieśnik, J. A case study of odour nuisance evaluation in the context of integrated urban planning. J. Environ. Manag. 2018, 213, 417-424. [CrossRef] [PubMed]

90. Ren, C.; Yang, R.; Cheng, C.; Xing, P.; Fang, X.; Zhang, S.; Wang, H.; Shi, Y.; Zhang, X.; Kwok, Y.T.; et al. Creating breathing cities by adopting urban ventilation assessment and wind corridor plan-The implementation in Chinese cities. J. Wind Eng. Ind. Aerodyn. 2018, 182, 170-188. [CrossRef]

91. Mirzaei, P.A.; Haghighat, F. A procedure to quantify the impact of mitigation techniques on the urban ventilation. Build. Environ. 2012, 47, 410-420. [CrossRef]

92. Arcadis Plan-MER, Masterplan Nieuw Zuide te Antwerpen. Available online: https://mer.lne.be/merdatabank/uploads/ merntech2924.pdf (accessed on 1 September 2019). (In Flemish).

93. Kang, J.E.; Yoon, D.K.; Bae, H.-J. Evaluating the effect of compact urban form on air quality in Korea. Environ. Plan. B Urban Anal. City Sci. 2019, 46, 179-200. [CrossRef]

94. Yu, H.; Stuart, A.L. Impacts of compact growth and electric vehicles on future air quality and urban exposures may be mixed. Sci. Total Environ. 2017, 576, 148-158. [CrossRef] [PubMed]

95. Smets, J.; De Blust, G.; Verheyden, W.; Wanner, S.; Van Acker, M.; Turkelboom, F. Starting a participative approach to develop local green infrastructure; from boundary concept to collective action. Sustainability 2020, 12, 10107. [CrossRef]

96. Wojnowski, W.; Wei, S.; Li, W.; Yin, T.; Li, X.X.; Ow, G.L.F.; Yusof, M.L.M.; Whittle, A.J. Comparison of absorbed and intercepted fractions of PAR for individual trees based on radiative transfer model simulations. Remote Sens. 2021, 13, 1069. [CrossRef]

97. Susca, T.; Gaf, S.R.; Osso, G.R.D. Positive effects of vegetation: Urban heat island and green roofs. Environ. Pollut. 2011, 159, 2119-2126. [CrossRef]

98. Scholz, T.; Hof, A.; Schmitt, T. Cooling Effects and Regulating Ecosystem Services Provided by Urban Trees-Novel Analysis Approaches Using Urban Tree Cadastre Data. Sustainability 2018, 10, 712. [CrossRef]

99. Baldauf, R. Roadside vegetation design characteristics that can improve local, near-road air quality. Transp. Res. Part D Transp. Environ. 2017, 52, 354-361. [CrossRef] [PubMed]

100. Department of Environment in Flanders. Expert Assignment on Street Clusters of Water, Sound, Air, Heat and Energy; Departement Omgeving: Brussels, Belgium, 2018. (In Flemish)

101. Greater London Authority. Using Green Infrastructure to Protect People from Air Pollution; Greater London Authority: London, UK, 2019. 